\title{
4
}

\section{Designing Optimal Software Patents}

\author{
Dan L. Burk and Mark A. Lemley
}

Over the past three decades, U.S. patent law has come to fully embrace the patentability of computer software, an acceptance that is at least arguably desirable and almost certainly irreversible. Software is at core a utilitarian artifact, better suited to the protective mechanisms of patent than those of the alternative copyright. ${ }^{1}$ As a practical matter, the software industry has long sought the inclusion of software within patentable subject matter and seems unlikely to surrender now that the goal has been achieved. Finally, although a few nations have fought a desperate rearguard action against software patenting, it has rapidly become the international standard, further consolidating the software patent norm.

In this chapter, we accept as given the proposition that patent law has a positive role to play in fostering software innovation, but argue that this will not occur as the state of software patenting currently stands. We suggest that the present contours of software patenting are poorly tailored to the realities of the industry, and require adjustment in order to foster software innovation. We begin by reviewing the current state of patent law vis-à-vis software, focusing on the patentability requirements of obviousness and disclosure. We describe in particular how the United States Court of Appeals for the Federal Circuit (CAFC), the court charged with jurisdiction for the matters of patent law, has developed a highly permissive disclosure standard for software, but a potentially restrictive obviousness standard. We then review the innovation profile of the software industry, noting its relatively low development costs, short product cycles, incremental development, and reliance on reverse

Copyright 2005 by Dan L. Burk and Mark A. Lemley. 
engineering. These characteristics, we argue, are poorly matched to the current scope and availability of software patents as developed elaborated by the CAFC. We conclude with certain suggestions as to how the contours of the software patents could be better fitted to the innovation needs of the software industry.

\section{Software Patents}

Software is presently well understood to be patentable subject matter, although this understanding is the result of a long and tortured history of doctrinal development. ${ }^{2}$ For many years, the United States Court of Appeals for the Federal Circuit moved by fits and starts toward declaring software patentable. Finally, with the late-1990s decisions in State Street Bank ${ }^{3}$ and ATET v. Excel, ${ }^{4}$ the court unreservedly admitted software to the canon of patentable subject matter. In doing so, the court emphasized that it was deciding only the question of subject matter: Whether software is the sort of invention that can be patented. ${ }^{5}$ For any given software invention, the remaining statutory criteria for patentability must by worked out on a case by case basis. ${ }^{6}$ These criteria include the requirement that the invention be novel, ${ }^{7}$ that is, not previously known; that the invention be nonobvious, ${ }^{8}$ that is, that it be a significant technological advance; and that it comply with statutory disclosure requirements. ${ }^{9}$ These patentability criteria must be met for all types of inventions. But the subsequent development of cases concerning these requirements has generated a unique and technology-specific set of criteria for software.

Disclosure. Section 112 of the U.S. Patent Act requires that patentees publish to the world a description of the invention sufficient to enable one of ordinary skill in the art to make and use it, as well as setting forth the "best mode" of implementing the invention. ${ }^{10}$ These requirements of enablement, description, and "best mode" are fundamental prerequisites for obtaining a patent. Indeed, this disclosure requirement is central to the patent policy "bargain" between patentees and the public; the public grants patent rights on condition of invention disclosure. ${ }^{11}$ Disclosure serves the public interest in two ways. First, disclosure enables competitors to make 
use of the patented invention once the patent expires, adding to the available knowledge in the art and ensuring that the invention ultimately enters the public domain. ${ }^{12}$ Second, during the term of the patent itself, disclosure enables others to improve on the patented technology, either by "designing around" the patent to produce a noninfringing variant ${ }^{13}$ or by developing a better version that, while infringing, is itself entitled to its own improvement patent. ${ }^{14}$

For software patents, however, a series of recent Federal Circuit decisions has drastically curtailed the enablement and best mode requirements. In recent years, the CAFC has held that software patentees need not disclose source or object code, flowcharts, or detailed descriptions of the patented program. Rather, the court has found high-level functional description sufficient to satisfy both the enablement and best mode doctrines. ${ }^{15}$ For example, in Northern Telecom, Inc. v. Datapoint Corp. ${ }^{16}$ the patent claimed an improved method of entering, verifying, and storing (or "batching") data with a special data entry terminal. The district court invalidated certain claims of the patent on the grounds that they were inadequately disclosed under section 112. The CAFC reversed. It held that, when claims pertain to a computer program that implements a claimed device or method, the enablement requirement varies according to the nature of the claimed invention as well as the role and complexity of the computer program needed to implement it. The court reasoned that, under the facts in this case, the core of the claimed invention was the combination of components or steps, rather than the details of the program the applicant actually used.

The court in Northern Telecom noted expert testimony to the effect that various programs could be used to implement the invention, and that it would be "relatively straightforward [in light of the specification] for a skilled computer programmer to design a program to carry out the claimed invention." 17 Indeed, the court continued to state that the expression of a desired function into programming language is "a mere clerical function to a skilled programmer."18 Similarly, in Fonar v. General Electric, ${ }^{19}$ discussing the patentee's obligation to disclose the best mode of practicing an invention, the Court explained that descriptions of software are "satisfied by a disclosure of the functions of the software" because "writing code for such software is within the skill of the art" once functions are disclosed. Thus, there is no need to disclose source code or detailed flow charts, only function. ${ }^{20}$ 
Indeed, in a few cases the CAFC has gone so far as to hold that patentees can satisfy the written description and best mode requirements for inventions implemented in software even though they do not use the terms computer or software anywhere in the specification of the invention!21 To be sure, in these latter cases, it would probably be obvious to one skilled in the art that the particular feature in question should be implemented in software. And one recent case moves in the other direction, holding that an oil drilling company failed to enable its method for calculating the location of a borehole when it kept all information about the computer programs used to perform the calculation secret.22 Still, it is remarkable that the CAFC is willing to find the enablement requirement satisfied by a patent specification that provides no guidance whatsoever on how the software should be written. ${ }^{23}$

Programming is a highly technical and difficult art. It is simply unrealistic to think that one of ordinary skill in the programming field can necessarily reconstruct a computer program given no more than the purpose the program is to perform. But the CAFC's peculiar direction in the software enablement cases has effectively nullified the disclosure obligation in those cases. And, since source code is normally kept secret, software patentees generally disclose little or no detail about their programs in the patent. Software patentees during the 1980s and early 1990s tended to write their patents in means-plus-function format ${ }^{24}$ in order to satisfy the changing dictates of the CAFC's patentable subject matter rules. ${ }^{25}$ Lawyers writing patents in such a format have an incentive to describe their invention in the specification in as general terms as possible, since means-plus-function claim elements will be limited to the actual structure disclosed in the specification and equivalents thereof. ${ }^{26}$ As a result, there is no easy way to figure out what a software patent owner has built except to reverse engineer the program. ${ }^{27}$

Obviousness. The disclosure requirement as applied to software has created a discrete body of precedent unique to that technology. But the court's reasoning in the enablement and best mode cases has another implication as well. Because the court views actually writing and debugging a program as a "mere clerical function" "within the skill of the art," it follows that the court is unlikely to consider the work of programming itself to be sufficiently innovative to meet the nonobviousness threshold of section 103. 
This is because patent law uses much the same test for gauging obviousness as for gauging adequacy of disclosure; In each case, the question of whether one of ordinary skill in the art be able to make the patented invention without undue experimentation is central to the inquiry. ${ }^{28}$

While only a limited number of appellate decisions discuss obviousness in the context of software patents, there is some reason to believe the court is imposing a rather strict standard. The first case involving the obviousness of a software-implemented invention is, perhaps surprisingly, a Supreme Court case from the 1970s. In Dann v. Johnston, ${ }^{29}$ the Court held a patent on a "machine system for automatic record-keeping of bank checks and deposits" invalid for obviousness. The Court took a rather broad view of obviousness in the computer industry, focusing on whether analogous systems to the patentee's had been implemented in computers before, rather than analyzing the precise differences between the patentee's program and the prior art programs. The clear implication of the opinion is that if a reasonably skilled programmer could produce a program analogous to the patented one, and if there was motivation in the prior art to do so, the patented program is obvious.

The Federal Circuit has found software patents invalid for obviousness in two recent cases, Lockwood v. American Airlines ${ }^{30}$ and Amazon.com v. Barnesandnoble.com. Inc. ${ }^{31}$ Neither case opined directly on the ease with which computer programs could be produced, but both viewed obviousness as a rather substantial hurdle to patentability of software. ${ }^{32}$ In Lockwood, the question was whether the defendant's own system made the patented claims obvious. The system had been in public use, but American Airlines had kept the workings of the system secret. Nonetheless, because Lockwood's patent was claimed in broad functional terms, the court found that similarly broad functional disclosures in the prior art were sufficient to render the patent obvious. While Lockwood argued that the information provided was not sufficient for one skilled in the art to make and use the system, the court pointed out that it was as detailed as the information Lockwood's own patent provided. ${ }^{33}$ Thus, the patent's meager disclosure of technical details indirectly contributed to the court's finding of obviousness.

In Amazon.com, the court found Amazon's "one-click" shopping feature to be obvious in view of certain references describing the desirability or feasibility of such a system in general terms, and one prior system that 
delivered data online in response to a mouse click. The court rejected arguments that the one-click feature was technically difficult to implement, relying on the fact that the prior art generally described such a system as both desirable and feasible. The court also gave surprisingly short shrift to Amazon's evidence of secondary considerations of nonobviousness. ${ }^{34}$

The likely result of the CAFC's focus on high-level functionality is that improvements in programming techniques will be found obvious in view of prior art that solved the same basic problem in a somewhat different way. This was arguably the result in both Dann and Lockwood, 35 and it seems to follow from the court's view in the section 112 cases that programmers are an extremely skilled group of individuals, who can write a given program with little guidance from the patentee. This also implies that for a program to be nonobvious to those of such skill in the art, it will have to be an extremely significant advance over the prior art. While disclosure is a minimal hurdle for software patents then, obviousness can be a rather tough one.

This argument may strike the reader as somewhat surprising. After all, legions of scholars and commentators complain that the Patent and Trademark Office (PTO) issues too many software patents, and in particular, it issues patents on subject matter that should be considered obvious. ${ }^{36}$ We agree with these commentators that the PTO is issuing bad software patents, in part because it cannot find relevant prior art. ${ }^{37}$ But our point is a different one: Those patents will not fare well in litigation because the CAFC will consider them obvious in view of any other computer program that implements the same basic concepts, regardless of how different those programs are in detailed implementation. Further, while hidden prior art is indeed a problem, parties in litigation have far more time and money to spend than patent examiners, and they are much more likely than the PTO to find the best prior art. The probable result is that, while numerous software patents will issue, a large number of those actually litigated will be found obvious.

Patent Scope. Patent scope is necessarily interrelated with obviousness and enablement. ${ }^{38}$ The breadth of patent protection is in part a function of how different the invention is from the prior art. Further, patent claims are invalid if they are not fully described and enabled by the patent specification, so the permissible breadth of a patent will be determined by how much information the court determines must be disclosed to enable one 
of ordinary skill in the art to make and use the patented invention. Obviousness and enablement also define patent law's doctrine of equivalents, which states that trivial substitutions in an allegedly infringing device will not place it beyond the scope of the patent, even if the substitutions are not explicitly claimed in the patent. The scope equivalents covered by a patent is a function of obviousness and enablement, since a patentee is not permitted to capture ground under the doctrine of equivalents that it would not have been permitted to claim in the first place. ${ }^{39}$

The CAFC's treatment of software validity issues suggests that, while the court will find relatively few software patents nonobvious, those that it does approve will be entitled to broad protection. The CAFC's decisions strongly suggest that a patent is nonobvious only if it is the first program to perform a given function. Most software patents will not meet this test, of course, but those that do will not be constrained by prior art to claim only their particular implementation of a function. They can claim the function itself. And the fact that they give little or no description of how to achieve this function will be no bar to the broad claims because the has proven remarkably unwilling to require software patentees to disclose details. As a result, we should expect the first to implement a new idea in software to claim the entire category of software, regardless of how second comers actually implement the same concept.

The evidence on software patent claim scope so far is mixed, although there is some evidence tending to support this hypothesis. Most notably, in Interactive Gift Express v. Compuserve, ${ }^{40}$ the patentee had designed a kiosk system for printing copyrighted works on demand. The CAFC held that the claims of the patent should be read broadly, to cover any form of online downloading in response to a remote request. ${ }^{41}$ In doing so, it reversed the district court's construction of five separate claim elements. As construed by the CAFC, the patent is breathtaking in its scope, and most electronic commerce sites that permit downloading of digital information are likely within its ambit.

The court's treatment of software patent scope under the doctrine of equivalents has been even less uniform. Many of these decisions have rejected application of the doctrine of equivalents to read claim language written for one product generation at such a high level of abstraction that it covers accused products from a different generation. Thus, in Alpex Computer Corp. 
v. Nintendo Co. ${ }^{42}$ the CAFC held that a patent claim to a video game output display system was not infringed by a next-generation system that worked in a different way. Alpex's claimed system included a display RAM that stored information corresponding to each pixel of a television screen in a discrete location. Nintendo's accused device, by contrast, used shift registers to store one "slice" of the video display at any given time. The CAFC rejected a jury finding that the two systems were equivalent. ${ }^{43}$ In Digital Biometrics, Inc. v. Identix, Inc. ${ }^{44}$ the court construed narrowly a patent claim to "image arrays" storing a two-dimensional slice of video data, which were merged into a "composite array" storing a fingerprint image. The court held that the defendant's systems, which constructed the composite array directly rather than by using two-dimensional slices, did not create "image arrays" within the meaning of the claims. More recently, in Wang Laboratories, Inc. v. America Online, 45 the court affirmed a district court decision granting summary judgment of noninfringement under the doctrine of equivalents. The patent claims in that case covered "frames," defined in the specification as pages encoded in character-based protocols. The court rejected Wang's attempt to extend the patent to cover bit-mapped pages, crediting evidence that there were "huge, huge differences" between the two approaches. ${ }^{46}$

Other cases have applied the doctrine of equivalents more broadly. In some of those cases, the CAFC has found equivalence between two different types of software programs written in different product generations. More troubling, some cases suggest that software implementations of certain ideas are equivalent to older mechanical implementations. An example is Overhead Door Corp. v. Chamberlain Group, Inc. ${ }^{47}$ The patented system claimed a (mechanical) switch connected to a microprocessor, which could store the codes of multiple garage doors. The CAFC held that the claim was not literally infringed by an electronic switch implemented in software. However, the court reversed a grant of summary judgment to the defendants under the doctrine of equivalents, concluding that a reasonable jury could find that the difference between mechanical and software implementations was a mere "design choice."

WMS Gaming, Inc. v. International Game Technology 48 is also instructive. In that case, the court held that a claim written in means-plus-function language that relied for its corresponding structure on a computer programmed with a particular algorithm was limited in literal scope to the 
particular algorithm chosen and equivalents thereof. However, the court found the defendant's algorithm infringing under the doctrine of equivalents, presumably because it was largely indifferent to which algorithm implemented the function of the program. This latter approach has the potential to expand the scope of patents in the software industry dramatically. ${ }^{49}$

Software patents, then, are likely to face serious obviousness hurdles. The few patents that overcome those hurdles need disclose virtually nothing about the detailed workings of their invention and will likely be broadly interpreted to cover a variety of mechanisms for implementing the basic software invention. We would expect the outcome of such a patent policy to be an industry dominated by a relatively small number of broad patents. This configuration of patents may be optimal for certain industries, for example, it fits well the innovation profile for the pharmaceutical industry where innovation costs are extremely high and product development times extremely protracted. But, as we show in the next section, the software patent criteria developed by the CAFC will lead not only to suboptimal results for software innovation but to a patent distribution that is decidedly detrimental to the industry.

\section{Software Innovation}

Patent law is our primary policy tool to promote innovation, encourage the development of new technologies, and increase the fund of human knowledge. Although there exist a variety of theories to explain how patents best accomplish this goal, there is virtually unanimous agreement that the purpose of the patent system is to promote innovation by granting exclusive rights to encourage invention. Industries vary in their innovation profiles, however, and in order to optimally encourage innovation, the scope of rights offered by a patent should match the needs of a given industry. Patents that would be perfectly tailored to the needs of one industry may be too narrow or too broad for another, failing in the first case to stimulate innovation investment or disastrously stifling innovative activity in the second.

Software is prime example of an industry with its own peculiar innovation requirements. The computer industry is characterized by a large number of rapid, iterative improvements on existing products. ${ }^{50}$ Computer 
programs normally build on preexisting ideas and often on prior code itself. ${ }^{51}$ This incremental improvement is desirable for a variety of reasons. First, it responds to the hardware-based architectural constraints of the software industry. Data storage capacity, processing speed, and transmission rates have all increased steadily over time. ${ }^{52}$ Programs written during an older period therefore faced capacity constraints that disappear over time. It makes sense to improve those products progressively as the constraints that limit the functionality of the programs disappear.

Second, incremental improvement of existing programs and ideas tends to render programs more stable. It is received wisdom in the industry that customers should avoid version 1.0 of any software product, because its maker is unlikely to have all the bugs worked out. Iterative programs built on a single base tend to solve these problems over time. This is most obviously true when actual computer code is reused, ${ }^{53}$ but it is true even when tested algorithms or structures are replicated in new programs. And as a related matter, iterative improvement helps preserve interoperability, both among generations of the same program and across programs. ${ }^{54}$

The software industry also has relatively low fixed costs and a short time to market. Software inventions tend to have a quick, cheap, and fairly straightforward postinvention development cycle. Most of the work in software development occurs in the initial coding, not in development or production. While the costs of writing software have increased substantially over time as programs have become more complex, the costs of writing and manufacturing computer programs remain low relative to the fixed costs of development in many industries. Debugging and test marketing is tedious and potentially time consuming, but it does not rival the cost of stringent safety testing and agency oversight that is necessary in other innovation sectors such as the biotechnology and pharmaceutical industries. ${ }^{55}$

Furthermore, computer program life cycles are short. The lead time to market in the software industry tends to be brief. Unlike industries, such as steel or aircraft, where new generations of products are infrequent and those products may last for decades, computer programs tend to be replaced every few years, and sometimes even yearly, often by new versions of the same program.

More critically, from the perspective of innovation policy, the ratio of innovation cost to the cost of follow-on competition is not particularly high. 
While it does cost less to clone someone else's program than to design your own from scratch, the difference is not enormous. ${ }^{56}$ This is in part because the capital investment requirement for software development is relatively low, consisting mostly of hiring personnel, not building laboratories or manufacturing infrastructure. The archetypal software invention is one made by two people working in a garage. ${ }^{57}$

Additionally, software development relies heavily on reverse engineering practices to allow either follow-on or compatible product development. Many commentators have explained the importance of permitting competitors to reverse engineer a product to see how it works and discover ways to design around it. ${ }^{58}$ Additionally, because software devices must interoperate with other software, reverse engineering is often important to producing compatible, let alone competing products. Decompilation of a competitor's object code is often an important step in producing new software products; software devices typically cannot be readily understood by casual inspection, and particularly not without access to human-readable source code or other documentation.

\section{Optimal Patent Design}

These industry characteristics are precisely those suggested by cumulative innovation theory. The economics of cumulative innovation map very well onto the modern software industry. The theory of cumulative innovation starts by rejecting the proposition that invention is an activity engaged in by a single inventor or company acting in isolation. Rather, cumulative innovation is an ongoing, iterative process that requires the contributions of many different inventors, each building on the work of others. ${ }^{59}$ Cumulative innovation theory questions the ability of any one inventor to identify and coordinate all the improvers needed to optimize a product over time. Instead, economists who emphasize cumulative innovation argue that the law must divide property entitlements to provide incentives to each improver in the process. The implications of these economic characteristics for patent law are threefold. First, the need for strong patent protection is somewhat less for software inventions than it is in other industries. Unlike paradigmatic patent-dependent industries, such as biotechnology and 
chemical manufacturing, where broad patent protection is critical due to high innovation cost and an uncertain development process, software development presents a relatively low-cost innovation profile. Software patents are important, but the relatively low fixed costs associated with software development, coupled with other forms of overlapping intellectual property protection for software, ${ }^{60}$ mean that innovation in software does not depend critically on strong, broad protection.

Second, the rapid, incremental innovation crucial to the software industry may be retarded by older companies that own software patents based on prior generations of products. The danger is that a single patent covers not just a single product, but several generations of products that reflect incremental improvements by a number of different companies. Cohen and Lemley offer several reasons to fear that the doctrine of equivalents may be applied too broadly in the software industry, allowing owners of old software patents to prevent the development of new generations of technology. ${ }^{61}$ It is worth noting, however, that the CAFC decisions on this point are decidedly mixed. ${ }^{62}$

Finally, a culture of rapid-fire incremental improvements leads to a large number of low-level innovations. Copyright is incapable of providing effective protection for such innovations because it does not protect functionality.63 Some form of protection for such innovations is desirable. Because innovation is relatively low cost but rapid, the need for patent protection is generally modest. Patent protection for such incremental software inventions should be relatively easy to acquire, but it should be narrow. In particular, software patents should not generally extend across several product generations. ${ }^{64}$ In the absence of other forms of protection, a large number of narrow software patents may be the best way of protecting these low-level innovations. 65

The question then is how to adjust current patent law to achieve this outcome of narrower and more-abundant patents. The patent statute itself provides the necessary tools. More than a decade ago, Robert Merges suggested that the nonobviousness doctrine should be adjusted commensurate with the costs of innovation in a given industry. ${ }^{66}$ The higher the cost to bring an invention to market, the bigger the potential reward should be, in order to attract the necessary investment. Bigger potential rewards can be provided by increasing the likelihood of obtaining a patent, and the 
likelihood of obtaining a patent can be increased by lowering the obviousness barrier. Conversely, the obviousness barrier should be heightened where the cost of innovation is lower and the need for a patent incentive is less.

Because innovation in software is relatively less uncertain than in industries like biotechnology, Merges's economic framework suggests that the nonobviousness bar should be rather high. ${ }^{67} \mathrm{~A}$ few broad software patents are indeed what the current CAFC jurisprudence will likely produce. By relaxing the enablement requirement and permitting software inventions to be defined in broad terms, supported by very little in the way of detailed disclosure, the CAFC has encouraged software patents to be drafted broadly and applied to allegedly infringing devices that are far removed from the original patented invention. By implication, the CAFC's standard also seems to suggest that many narrower software patents on low-level incremental improvements will be invalid for obviousness in view of earlier, more general disclosures. They may also be invalidated under the on-sale bar, because the Supreme Court's view that a software invention is "ready for patenting" 68 when it is the subject of a commercial order and when the inventor has described its broad functions, even if it is not clear how the code will be written or that it will work for its intended purpose, ${ }^{69}$ means that any patentee who waits until the code is written to file a patent application risks being time-barred for not filing earlier.

Unfortunately, when matched up against actual industry needs, the CAFC's current standard seems to be precisely backward. Software is an industry characterized, at least to a limited extent, by competition theory ${ }^{70}$ and, to a greater extent, by cumulative innovation. Cumulative innovation theory suggests that patent protection for incremental software inventions should be relatively easy to acquire in order to reward incremental improvements, implying a somewhat lower obviousness threshold. It also suggests that the resulting patents should be narrow and, in particular, that they should not generally extend across several product generations for fear of stifling subsequent incremental improvements. This in turn means that software patents should be limited in scope. ${ }^{71}$

Implementing a rational software policy obviously requires some significant changes to existing case law. A number of patentability doctrines might be brought to bear on this problem. First, obviousness doctrine needs to be reformed, preferably by way of a more informed application of 
the level of skill in the art ${ }^{72}$ or, alternatively, by application of new secondary considerations of nonobviousness. ${ }^{73}$ Second, a higher disclosure requirement and restrictions on the doctrine of equivalents will help reduce patent scope. ${ }^{74}$

Additionally, the reverse engineering needs of the software industry are not accommodated under current patent law. In the case of copyright, courts have adapted the doctrine of fair use, sometimes together with copyright misuse, to allow competitors to engage in reverse engineering of computer software. ${ }^{75}$ Patent law, however, includes no express provision allowing reverse engineering, nor is there any judicially developed exception akin to copyright's fair use doctrine that might permit it. Indeed, patent law generally lacks provisions akin to fair use or other exceptions that might readily be pressed into the service of reverse engineering, although commentators have suggested that patent law may need such exceptions for precisely this reason. ${ }^{76}$

This does not mean that reverse engineering a patented product is necessarily illegal under patent law. Some inventions, such as the paper clip, are readily apparent once embodied in a product. ${ }^{77}$ Improvers do not need to reverse engineer the paper clip to determine how it works in order to improve it; they just need to look at it. Additionally, in many cases, the patentee has done all the work necessary for reverse engineering patented inventions by disclosing how to make and use the claimed invention in the patent specification. In theory, an express provision authorizing reverse engineering would be superfluous if the enabling disclosures required to secure a patent were sufficiently strong: Someone who wanted to learn how a patented device worked would need only to read the patent specification. ${ }^{78}$

Patentable inventions in software, however, generally do not have these characteristics. ${ }^{79}$ Examination of the patent itself is unlikely to yield information equivalent to a reverse engineered inspection because the CAFC does not require would-be patentees of software inventions to disclose the implementing source code or, for that matter, very much at all about their inventions. ${ }^{80}$ Accordingly, software patents present unique obstacles to consummation of the patent law's traditional rights-for-disclosure bargain with the public.

The specific reverse engineering techniques commonly used for software, in turn, may raise some infringement problems that are unique to software. The definition of infringement in the patent statute is extremely 
broad, encompassing anyone who "makes, uses, offers to sell, . . . sells . . . , or imports" a patented product. ${ }^{81}$ Reverse engineering a patented computer program by decompiling 82 it likely fits within this broad category of prohibited conduct, at least where the program itself is claimed as an apparatus. Reverse engineering clearly constitutes a "use" of the patented software, although owners of a particular copy of the program surely have the right to use it. ${ }^{83}$ More significantly, decompilation may also constitute "making" the patented program by generating a temporary yet functional copy of it in RAM memory ${ }^{84}$ and, in certain instances, a longer-term (though still "intermediate") copy in more permanent memory. Thus, an article-of-manufacture claim to a particular program "encoded on a computer hard drive" might be infringed by a reverse engineered copy temporarily stored on a computer hard drive. Those copies probably constitute patent infringement unless protected by some defense. The result of all of this is that the nominally neutral patent law rule-no defense for reverse engineering-affects software more than other industries.

The need for a reverse engineering exception in patent law militates in favor of adapting the existing doctrines of exhaustion or experimental use to that end. 85 Patent misuse might also be adapted, as it has been in the copyright arena, to prevent patent holders from deterring or prohibiting reverse engineering related to their inventions. The exception might even be created by reinterpreting the infringement provisions of Section 271(a). The resulting patent doctrine would constitute a macro policy lever. As Cohen and Lemley observe, in most industries there is either no need to reverse engineer an invention or reverse engineering can be done without infringing the patent. ${ }^{86}$ Only in software is there a need for a particular doctrine to protect the right to reverse engineer, and therefore the ability of improvers to innovate. Thus, a judicially created reverse engineering defense would make sense across the board in software cases but not in other patent cases.

\section{Institutional Competence}

This tailoring of patent law to accommodate the innovation profile of software requires the active interpretation and reinterpretation of flexible standards embedded in the patent statute. We believe that the patent statute is 
properly designed to facilitate precisely such interpretive activity and that courts both can and should use their common-law rulemaking discretion to engage in deliberate, industry-specific modulation of the statute. ${ }^{87}$ The business of innovation is too dynamic for the patent system to function successfully in any other way. Not only do new technologies come into existence and old technologies fade into obscurity, but the innovation profile of industries varies from sector to sector and from time to time. Broad disparities exist across economic sectors in the cost of research and development, the length of product cycles, the return on investment, and the cost of obtaining patents itself. The incentives necessary to promote innovation in the pharmaceutical industry are not those necessary to software or to semiconductors. The incentives necessary to a mature software industry are not those that were once necessary to nascent software developers.

Legislative Competence. Only a dynamically interpreted statute can hope to meet the needs of so many disparate industries. The likelihood that a unitary, unvarying, and monolithic statute could supply the correct level of incentive under so many circumstances is essentially nil. The prospect for the legislature to continually revisit the circumstances of each industry and pass appropriate new legislation for each situation is equally untenable; as Grant Gilmore long ago observed, "[G]etting a statute enacted in the first place is much easier than getting the statute revised so that it will make sense in the light of changed conditions." 88 In democratically elected legislatures, an enormous commitment of political capital is typically required to draft, promulgate, and reach consensus on new intellectual property legislation, especially if the legislation is to be supported by credible factfinding and reliable expertise. The issues involved here are typically not magnets of populist sentiment, and are more likely to be viewed as esoteric and obscure to voters. We can anticipate serious legislative investigation of, and response to, specialized industry needs to be relatively rare events.

But past experience with such specialized statutes is not encouraging. In the United States, the poster child for failed sui generis legislation has been the notoriously neglected Semiconductor Chip Protection Act, or (SCPA). Passed at the behest of the U.S. semiconductor industry after six years of legislative debate, the SCPA created a detailed set of rules designed to protect the "mask work" or circuit design pattern etched into 
semiconductor chips. The statute was tailored specifically to the purported needs of the industry, including special provisions on reverse engineering and other practices common to semiconductor circuit design. The ostensible reason was to protect American innovation from foreign competitors. But the statute has virtually never been used to enforce the rights it created, generating only one published judicial opinion since its enactment. ${ }^{89}$ The most likely reason is that the particular focus of the SCPA-duplication of mask works-is obsolete because the nature of the semiconductor business changed to make the manufacturing process much more difficult, hence harder to imitate at low cost. ${ }^{90}$ The foreign competition so feared by U.S. chip fabricators has all but vanished, and the industry appears to be thriving without recourse to its specialized statute.

A similar story could be told regarding industry-specific patent statutes, such as the biotechnology-specific amendments to the U.S. patent statute's obviousness provisions. ${ }^{91}$ Like the SPCA, the biotechnology obviousness provisions were enacted after lobbying by the biotechnology industry, which claimed that the general standard for obviousness failed to meet the special process-based characteristics of their industry, requiring a sui generis standard. But the biotechnology amendment became irrelevant nearly as soon as it was enacted, in part because general patent standards now reach the same result, ${ }^{92}$ and lack the more onerous procedural requirements of the specialized provision.

Preliminary studies of the U.S. Plant Patent Act and Plant Variety Protection Act, as well as the European Union's relatively recent database directive, suggest that similar stories might be told in the case of those specialty statutes as well. ${ }^{93}$ The sorry history of such industry-specific statutes suggests that they typically turn out to be failures, because they are drafted with the technology at the time of their passage in mind and are not sufficiently general to accommodate the inevitable changes in technology. This general problem with statutory obsolescence was identified by Guido Calabresi more than twenty years ago, ${ }^{94}$ and becomes particularly acute in the case of technologically oriented statutes. ${ }^{95}$ Indeed, the likely disinterest of the general populace in such legislative amendments lends itself to a corollary and more serious concern as predicted by both public choice theory and by practical experience. ${ }^{96}$ Each time the legislature reopens the patent statute to amendment, the opportunity arises for counterproductive 
lobbying by special interest groups, not the least of which will be the industry to which the amendment is directed. Technology-specific patent legislation encourages rent-seeking, either by those who stand to benefit directly from favorable legislation or by those who will seize each new legislative opportunity to hijack the amendment process for their own benefit. This has been the history of the U.S. copyright statute, where industry-specific rules and exceptions have led to a bloated, impenetrable statute that reads like the tax code, which is itself the product of such special-interest rentseeking. ${ }^{97}$ Patent law has some balance today in part because different industries have different interests, making it difficult for one interest group to push through changes to the statute. Industry-specific legislation is much more vulnerable to industry capture. It is no accident that the industry-specific portions of the patent law are among the most complex and confusing sections, ${ }^{98}$ and have had some pernicious consequences. ${ }^{99}$

Judicial Competence. These shortcomings in the legislative process militate in favor of judicial oversight for industry-specific tailoring of innovation incentives. This viewpoint stands admittedly at odds with the conventional view that legislatures carry an inherent institutional advantage in detailed fact-finding, and in reflecting social consensus. However, statutes exist on a continuum. At one end lie the kind of tightly drafted detailed rules, such as the U.S. tax code, that Grant Gilmore characterized as "aimed at an unearthly and superhuman precision." 100 As Gilmore noted, such statutes are drafted precisely to curtail judicial interpretation but are nearly impossible to adjust "to changing conditions without legislative revision." 101

At the other end of the continuum lie general delegations of authority to judges to make correct decisions. ${ }^{102}$ The U.S. Sherman Act presents a good example of such a statute, where a set of relatively short directions have generated a robust body of antitrust law. While the statute sets the basic parameters for patentability and infringement, it does not specify in any detail how those basic principles are to be applied. And, in many instances, judicially created doctrines have played a major role in defining the scope of patent protection. ${ }^{103}$ Such tailoring activity necessarily vests a fair degree of discretion in the judiciary in order to adapt the general statute to the particular circumstance. 
As a general principle, a flexible approach, favoring ongoing judicial oversight, best accommodates new and different technologies within the general framework of a patent statute. Skeptics about the relative merits of judicial oversight may with some justification object that litigation is not cost free and that the courts, appellate courts in particular, are not entirely immune from problems of public choice. However, all advantages are comparative, and the question is not whether courts are the perfect policy tailors, but whether, given the evils of industry-specific statutes here described, courts are better situated to engage in tailoring than the legislature. Court-based tailoring occurs within a particular context, whereby litigation costs purchase not only resolution of a private dispute but the public good of judicial decision making, the costs of dispute resolution in effect subsidize statutory upkeep. Within this context, courts have substantial ability to profile an industry and adapt competition policy according to the profile, within a reasonable time frame and at reasonable cost. Courts are routinely expected to fill this function in areas such as antitrust. Common-law courts can fulfill a similar role in patent law and have indeed done so with regard to a variety of other patentability criteria.

Agency Competence. Courts and legislatures, of course, are not the only institutions available to address statutory upkeep; administrative agencies constitute a third option. There is an argument sometimes made that agencies offer the best of both institutional worlds, having greater expertise and investigatory resources than courts, without the special-interest rent-seeking of legislatures. But, in reality, it is probably necessary to recognize that the middle road of administrative agencies to some extent partakes of the worst of both worlds. ${ }^{104}$ Administrative agencies are by no means independent from the legislative forces of public choice, and the same legislator who succumbs to the pressure of special interest groups likely controls the budget of the agency that deals with those groups. ${ }^{105}$ But, at the same time, neither is the staff of the administrative agency directly accountable to voters, removing even the threat that voters might overcome collective action problems to impose discipline on imprudent or improper actions. Additionally, the problem of direct capture may be greatly exacerbated in this context. To the extent that an administrative agency interacts repeatedly with a particular constituency, especially a constituency with whom it shares particular expertise, that 
constituency is likely to exercise undue influence on the agency's rule-making process.

This is not to say that an agency, in this particular case the Patent Office, cannot play a carefully modulated adjunct role in statutory upkeep. Most particularly, there may be such a role if the agency can be held to what it does best, which is fact-finding, without becoming involved in setting legal standards, which is the strong suit of the courts. In this regard, it is important to note that the Supreme Court has extended to the Patent Office a standard of review that grants it judicial deference in fact-finding, without (so far) granting deference in statutory interpretation. ${ }^{106}$ This may be in part intended to temper the discretion vested in the specialized patent jurisdiction of United States Court of Appeals for the Federal Circuit. ${ }^{107}$ Nonetheless, even allowing for a fact-finding role on the part of the Patent Office, the modulation of legal standards for particular industries remains in the hands of the courts, and the courts remain the best institutional choice available for that particular role.

\section{Conclusion}

Current doctrinal approaches to software patenting have been characterized by high obviousness barriers and low disclosure barriers, a recipe for generating a few dominant patents of broad scope. But this is precisely the wrong outcome for an industry characterized by rapid, cumulative, and incremental innovation. By adjusting the doctrines of obviousness and disclosure to allow narrower but more frequent patenting, as well as by invoking experimental use and related doctrines to permit reverse engineering, courts can tailor the patent system to better serve the innovation needs of software production. 


\section{Notes}

1. Copyright is designed to protect aesthetic rather than functional creations and in fact excludes functional or utilitarian works from its scope. See Dan L. Burk, "Patenting Speech," Texas Law Review 79 (2000): 100.

2. See, e.g., Julie E. Cohen and Mark A. Lemley, "Patent Scope and Innovation in the Software Industry," California Law Review 89 (2001): 1; Pamela Samuelson, "Benson Revisited: The Case against Patent Protection for Algorithms and Other Computer Program-Related Inventions," Emory Law Journal 39 (1990): 1025, 1033, n. 24.

3. State Street Bank \& Trust v. Signature Fin. Group, 149 F.3d 1368 (Fed. Cir. 1998).

4. ATET Corp. v. Excel Communications, 172 F3d 1352 (Fed. Cir. 1999).

5. 35 U.S.C. $\$ 101$.

6. See State Street, 149 F.3d at 1375. Indeed, on remand in ATET, the district court held the patent invalid under section 102. ATET Corp. v. Excel Communications, 52 U.S.P.Q.2d 1865 (D. Del. 1999).

7. 35 U.S.C. $\$ 102$.

8. 35 U.S.C. $\$ 103$.

9. 35 U.S.C. $\$ 11291$.

10. 35 U.S.C. $\$ 112$ \$1 (1994).

11. One classic justification for having a patent system is to encourage inventors to disclose their ideas to the public, who will benefit from this new knowledge once the patent expires. Kewanee Oil Corp. v. Bicron Corp., 416 U.S. 470, 489 (1974) (referring to the "federal interest in disclosure" embodied in the patent laws); see also Edith Tilton Penrose The Economics of the International Patent System (John Hopkins University Press, Baltimore, 1951), 31-34.

12. Without the disclosure obligation, patentees could conceivably keep the workings of their inventions secret, relying on that secrecy to extend protection even after the patent has expired. Cf. Pitney-Bowes v. Mestre, 701 F.2d 1365, 1372 n.12 (11th Cir. 1983) (discussing the policy concerns here).

13. State Indus. v. A.O. Smith Corp., 751 F.2d 1226, 1236 (Fed. Cir. 1985) ("One of the benefits of a patent system is its so-called 'negative incentive' to 'design around' a competitor's products, even when they are patented, thus bringing a steady flow of innovations to the marketplace."); Craig Allen Nard, "Toward a Pragmatic Textualist Approach to Claim Interpretation," Harvard Journal of Law and Technology 14 (2000): 1 [SII.C.2] ("The practice of designing around extant patents creates viable substitutes and advances, resulting in competition among patented technologies. The public clearly benefits from such activity").

14. See, e.g., Mark A. Lemley, "The Economics of Improvement in Intellectual Property Law," Texas Law Review 75 (1997): 989; Robert P. Merges, "Intellectual Property Rights and Bargaining Breakdown: The Case of Blocking Patents," Tennessee Law Review 62 (1994): 75; Robert P. Merges and Richard R. Nelson, "On the Complex 
Economics of Patent Scope," Columbia Law Review 90 (1990): 839; Suzanne Scotchmer, "Standing on the Shoulders of Giants: Cumulative Research and the Patent Law," Journal of Economic Perspectives 4 (1991): 29; Jerry R. Green and Suzanne Scotchmer, "On the Division of Profit in Sequential Innovation," RAND Journal of Economics 26 (1995): 20; Suzanne Scotchmer, "Protecting Early Innovators: Should Second-Generation Products be Patentable?" RAND Journal of Economics 27 (1996): 322; Howard F. Chang, "Patent Scope, Antitrust Policy, and Cumulative Innovation," 26 RAND Journal of Economics 26 (1995): 34; James B. Kobak Jr., "Intellectual Property, Competition Law and Hidden Choices between Original and Sequential Innovation," Virginia Journal of Law and Technology 3 (1998): 6; Clarisa Long, "Proprietary Rights and Why Initial Allocations Matter," Emory Law Journal 49 (2000): 823.

15. See Fonar Corp. v. General Electric Co., 107 F.3d 1543, 1549 (Fed. Cir. 1997); see also Lawrence D. Graham and Richard O. Zerbe Jr., "Economically Efficient Treatment of Computer Software: Reverse Engineering, Protection, and Disclosure," Rutgers Computer and Technology Law Journal 22 (1996): 61, 96-97; Anthony J. Mahajan, "Note, Intellectual Property, Contracts, and Reverse Engineering after ProCD: A Proposed Compromise for Computer Software," Fordham Law Review 67 (1999): 3297, 3317.

16. 908 F.2d 931 (Fed. Cir.), cert. denied, 111 S. Ct. 296 (1990).

17. Ibid., 941-42.

18. Ibid.

19. 107 F.3d 1543 (Fed. Cir. 1997).

20. Ibid., 1549 (citations omitted).

21. Robotic Vision Sys., Inc. v. View Eng'g, Inc., 112 F.3d 1163 (Fed. Cir. 1997) (best mode); In re Dossel, 115 F.3d 942 (Fed. Cir. 1997) (written description).

22. Union Pacific Resources v. Chesapeake Energy Co., 236 F.3d 684, 690-91 (Fed. Cir. 2001).

23. One recent decision even found that a specification that provided inconsistent guidance as to how the invention worked was not indefinite. See S3 Corp. v. Nvidia Corp., 259 F.3d 1364 (Fed. Cir. 2001); compare ibid., 1371 (Gajarsa, J., dissenting). 24. See 35 U.S.C. $\$ 112$, 16.

25. For an example, see In re Alappat, 33 F.3d 1526 (Fed. Cir. 1994) (en banc).

26. Ibid.

27. On the perils of reverse engineering patented software, see Cohen and Lemley, "Patent Scope and Innovation," 17-21. Cited in note 2.

28. Compare In re Vaeck, 947 F.2d 488 (Fed. Cir. 1991) (levels of experimentation and skill in the art in obviousness test) with In re Wands, 858 F.2d 731 (Fed. Cir. 1988) (levels of experimentation and skill in the art in enablement test). See also Donald S. Chisum, "Anticipation, Enablement and Obviousness: An Eternal Golden Braid," AIPLA Quarterly Journal 15 (1987): 57 (discussing the fundamentally interrelated nature of the obviousness and enablement inquiries). 
29. 425 U.S. 219 (1976).

30. 107 F.3d 1565 (Fed. Cir. 1997).

31. 239 F.3d 1343 (Fed. Cir. 2001).

32. In In re Zurko, 111 F.3d 887 (Fed. Cir. 1997), the CAFC held that a patented software invention was nonobvious even though each of the elements of the invention could be found in the prior art, where the prior art did not identify the problem to be solved. While Zurko certainly demonstrates that some software patents will be held nonobvious, it is a specific holding of rather limited utility to most software patentees.

33. $107 \mathrm{~F} .3 \mathrm{~d}$ at 1570 .

34. Amazon.com v. Barnesandnoble.com, 239 F.3d 1343, 1366 (Fed. Cir. 2001).

35. See also Electronic Planroom v. McGraw-Hill Cos., 135 F. Supp. 2d 805 (E. D. Mich. 2001).

36. See, e.g., Robert P. Merges, "As Many as Six Impossible Patents before Breakfast: Property Rights for Business Concepts and Patent System Reform," Berkeley Technology Law Journal 14 (1999): 577; Julie E. Cohen, "Reverse Engineering and the Rise of Electronic Vigilantism: Intellectual Property Implications of 'Lock-Out' Technologies," Southern California Law Review 68 (1995): 1091, 1179; Glynn S. Lunney Jr., "E-Obviousness," Michigan Telecommunication and Technology Law Review 7 (2000-2001): 363.

37. Cohen, ibid. See also Cohen and Lemley, "Patent Scope and Innovation,"42-44, cited in note 2; Greg Aharonian, http://www.bustpatents.com. But cf. John R. Allison and Mark A. Lemley, "Who's Patenting What? An Empirical Exploration of Patent Prosecution," Vanderbilt Law Review 53 (2000): 2099, 2131-32 (software patents actually cite slightly more nonpatent prior art than other types of patents).

38. See Chisum, "Anticipation, Enablement and Obviousness." Cited in note 28.

39. See Wilson Sporting Goods v. David Geoffrey \& Assoc., 904 F.2d 677 (Fed. Cir. 1990).

40. 256 F.3d 1323, (Fed. Cir. 2001).

41. Ibid.

42. 102 F.3d 1214 (Fed. Cir. 1996).

43. Ibid. at 1222. To similar effect as Alpex is Wiener v. NEC Elec., Inc., 102 F.3d 534 (Fed. Cir. 1996). In that case, the CAFC upheld the district court's finding of noninfringement under the doctrine of equivalents, because there were substantial differences between the patent's requirement that a computer program "call on" columns of data one byte at a time and the defendant's product, in which the columns alleged to be equivalent were not in the data matrix, and therefore were not called on to read data. The court rejected the "conclusory" declaration of plaintiff's expert that the two processes were identical.

44. 149 F.3d 1335 (Fed. Cir. 1998).

45. 197 F.3d 1377 (Fed. Cir. 1999). 
46. Ibid. at 1386. See also Netword LLC v. Centraal Corp., 58 U.S.P.Q.2d 1076 (Fed. Cir. 2001) (claim requiring caching of data by local servers that pulled information from a central registry not infringed under the doctrine of equivalents by a system in which all local computers hold full copies of the central registry).

In a related context (interpreting equivalent structure in a means-plus-function claim), the court held that Nintendo's video game systems did not infringe GE's television switch patents because the patents, written in means-plus-function format, did not disclose a function for the switches identical to Nintendo's function. General Electric Co. v. Nintendo Co., 179 F.3d 1350 (Fed. Cir. 1999). On how the doctrine of equivalents differs from equivalence under a means-plus-function analysis, see Chiuminatta Concrete Concepts, Inc. v. Cardinal Indus., 145 F.3d 1303 (Fed. Cir. 1998). 47. 194 F.3d 1261 (Fed. Cir. 1999).

48. 184 F.3d 1339 (Fed. Cir. 1999).

49. For an argument that a variety of structural tendencies are likely to drive the courts to read software patent claims broadly under the doctrine of equivalents, see Cohen and Lemley, "Patent Scope and Innovation," 39-50. Cited in note 2.

50. See ibid., 40-42; Peter S. Menell, "Tailoring Legal Protection for Computer Software," Stanford Law Review 39 (1987): 1329, 1369-70; Samuelson et al., "A Manifesto Regarding the Legal Protection of Computer Programs," Columbia Law Review, 94 (1994): 2308, 2376.

51. For more on the reuse of existing code, both within and across companies, see Mark A. Lemley and David W. O’Brien, "Encouraging Software Reuse," Stanford Law Review, 49 (1997): 255, 261-66.

52. In 1965, Gordon Moore, cofounder of Intel, observed that, historically, the speed of microprocessors has doubled every year. See Webopedia, "Moore's Law" (March 22, 1998), at http://www.webopedia.come/TERM/M/Moores_Law.html. The current definition of Moore's law, as this phenomenon has been dubbed, is that data density doubles every eighteen months (ibid.). It is well known that data storage capacity and transmission rates have shown similarly exponential increases.

53. See Lemley and O'Brien "Encouraging Software Reuse", 265. Cited in note 51.

54. For the same reason, reverse engineering has had a respected place as a legitimate means of creating interoperability. Virtually all recent copyright decisions have endorsed reverse engineering in some circumstances. See, e.g., DSC Communications Corp. v. DGI Techs., Inc., 81 F.3d 597, 601 (5th Cir. 1996) (holding that the manufacturer was unlikely to succeed on the merits of its claim that a competitor infringed a copyright on an operating system when it downloaded software onto microprocessor cards for testing); Bateman v. Mnemonics, Inc., 79 F.3d 1532, 1539 n.18 (11th Cir. 1996) (affirming acceptability of reverse engineering code); Lotus Dev. Corp. v. Borland Int'l, Inc. 49 F.3d 807, 817-18 (1st Cir. 1995) (Boudin, J., concurring) (endorsing reverse engineering); Sega Enters. Ltd. v. Accolade, Inc., 977 F.2d 1510, 1527-28 (9th Cir. 1992) (holding that disassembly is fair use within the scope of that exception under copyright law); Atari Games Corp. v. Nintendo of Am., Inc., 975 F.2d 832, 
843-44 (Fed. Cir. 1992) (refusing to find reverse engineering to be copyright infringement); Vault Corp. v. Quaid Software Ltd., 847 F.2d 255, 270 (5th Cir. 1988) (holding unenforceable a provision in a license agreement prohibiting reverse engineering); Mitel, Inc. v. Iqtel, Inc., 896 F. Supp. 1050, 1056-57 (D. Colo. 1995), aff'd on other grounds, 124 F.3d 1366 (10th Cir. 1997) (endorsing the Ninth Circuit's approach in Sega v. Accolade).

55. See notes 50-57 and the accompanying text (making these points in more detail).

56. For a contrary view, see Patrick K. Bobko, "Open-Source Software and the Demise of Copyright," Rutgers Computer and Technology Law Journal 27 (2001): 51, 58-60 (arguing that the ratio of development to imitation costs in software is extremely high). It is trivially easy to counterfeit existing software, but it is illegal under copyright law, and the relevant costs are the costs of legal imitation under a regime without patents.

57. Hewlett and Packard and Jobs and Wozniak are the classic examples, but the story has taken on a life of its own. See, e.g., Micalyn S. Harris, "UCITA: Helping David Face Goliath," John Marshall Journal Computer and Information Law 18 (1999): 365,375 .

58. See, e.g., Cohen and Lemley, "Patent Scope and Innovation." Cited in note 2.

59. See Scotchmer, "Standing on the Shoulders of Giants" 29. Cited in note 14.

60. Copyright law is the predominant protection for software, but trade secret and contract law also provide protection. One factor militating in favor of stronger intellectual property protection in software is the ease of duplication of digital information in the networked world. Copyright protection is much better suited to preventing exact duplication than patent protection, however. Copyright law has also been modified to better prevent such copying in the computer context by allowing copyright owners to control access to copy-protected works. See The Digital Millennium Copyright Act, 17 U.S.C. §1201 (2003).

61. Cohen and Lemley, "Patent Scope and Innovation," 39-50. Cited in note 2.

62. Ibid., 54-56.

63. For a detailed discussion, see Samuelson et al., "A Manifesto," cited in note 50; Pamela Samuelson, "CONTU Revisited: The Case against Copyright Protection for Computer Programs in Machine-Readable Form," Duke Law Journal (1984): 663, 733.

64. See generally Richard R. Nelson, "Intellectual Property Protection for Cumulative Systems Technology," Columbia Law Review 94 (1994): 2674 (arguing for a moderate protection scheme to meet the protective needs of the software industry).

65. Pamela Samuelson worries that software patents may be too broad, given the incremental nature of software innovation. Samuelson et al., "A Manifesto" 2345-46, cited in note 50; see also Samuelson, "Benson Revisited," cited in note 2 (arguing against protecting software with patents). As noted later, we share this concern but believe that the solution is to narrow the scope of those patents. 
Some might object to a large number of software patents because they increase the transaction costs of inventing. We are not persuaded, however, that software patents of modest scope will increase transaction costs much more than software copyrights do. The only relevant patents are those that are licensed or litigated-less than five percent of the total number-not the whole universe of patents. See Mark A. Lemley, "Rational Ignorance at the Patent Office," Northwestern University Law Review, 95 (2001): 1495, 1507. If those patents are of modest scope, they do not present opportunities for their owners to impede largely unrelated technologies, and the transaction costs should be relatively modest.

66. Robert P. Merges, "Uncertainty and the Standard of Patentability," High Technology Law Journal 7 (1992): 1.

67. See ibid., 29-32.

68. See Pfaff v. Wells Elecs., 525 U.S. 55, 67-69 (1998).

69. See Robotic Vision Sys. v. View Eng'g, 249 F3d 1307, 1311-13 (Fed. Cir. 2001).

70. The success of the open source movement suggests that significant innovation can occur in the software industry in the absence of intellectual property protection, although it does not follow that we would get as much or the same kinds of innovation were we to abolish intellectual property protection for software outright. For discussions of the open source movement, see Yochai Benkler, "Coase's Penguin, or, Linux and the Nature of the Firm," Yale Law Journal 112 (2002): 369; David McGowan, "Legal Implications of Open-Source Software," University of Illinois Law Review (2001): 241.

71. Jim Bessen and Robert Hunt find that software patents tend to be issued to manufacturing companies, not software developers, and that they are consistent with strategic "patent thicket" behavior. James Bessen and Robert M. Hunt, "An Empirical Look at Software Patents" (working paper 03-17/R, http://www.phil. frb.org/files/wps/2003/wp03-17.pdf May 2003). If they are correct, it is further evidence that the scope of software patents should be reduced to eliminate the overlap problem.

72. Dan L. Burk and Mark A. Lemley, "Is Patent Law Technology-Specific?" Berkeley Technology Law Journal 17 (2003): 1155, 1202-5.

73. See, e.g., ibid. (suggesting cost and uncertainty of postinvention development as a new secondary consideration supporting nonobviousness).

74. See, generally, Richard R. Nelson, "Intellectual Property Protection for Cumulative Systems Technology," Columbia Law Review 94 (1994): 2674 (discussing the need to reduce the scope of patents in the software industry).

75. See note 54 and the accompanying text.

76. Maureen A. O'Rourke, "Toward a Doctrine of Fair Use in Patent Law," Columbia Law Review 100 (2000): 1177.

77. See, e.g., U.S. Patent No. 5,179,765 (issued Jan. 19, 1993) (for a "Plastic Paper Clip").

78. 35 U.S.C. $\$ 112(2000)$. 
79. Samuelson and her colleagues argue that certain features of computer programs are readily apparent to competitors and are therefore vulnerable to copying. Samuelson et al., "A Manifesto," cited in note 50, 2333. Their argument, however, depends not only on the vulnerability of programming innovations to casual inspection but also on the ability of competitors to reverse engineer and analyze the design know-how lying "near the surface" of a program. Ibid., 2335-37. If patent law precludes reverse engineering, it also precludes this sort of knowledge. It is true that certain types of computer program innovations, particularly user interfaces, are necessarily available to even the casual user, at least in part. It is unlikely, however, that these innovations are the most significant parts of a new computer program or the parts most likely to be patented. Further, those innovations for which precise understanding is most important (such as application program interfaces) are also those that will not be available to casual inspection.

80. See notes $16-27$ and the accompanying text.

81. 35 U.S.C. $\$ 271$ (a) (2000).

82. We should be clear that we are concerned primarily with reverse engineering by "decompilation," that is, working backward from the object code to construct a simulacrum of the source code. Other forms of reverse engineering, such as "blackbox" reverse engineering, do not involve making even temporary copies of the program, although they certainly involve "using" it. Our discussion of "reverse engineering" should be understood to refer to decompilation, not to black-box reverse engineering.

83. For further discussion of the implied license and exhaustion doctrines that confer such a right, see Cohen and Lemley, "Patent Scope and Innovation," 30-35. Cited in note 2.

84. Keith E. Witek, "Software Patent Infringement on the Internet and on Modern Computer Systems-Who Is Liable for Damages?" Santa Clara Computer and High Technology Law Journal 14 (1998): 303, 323-24.

85. Cohen and Lemley explain how the doctrines of exhaustion and experimental use might be modified to create a right to reverse engineer patented software. Cohen and Lemley, "Patent Scope and Innovation," 29-35. Cited in note 2

86. See ibid., 23-25.

87. See Burk and Lemley, "Is Patent Law Technology Specific?" Cited in note 72.

88. Grant Gilmore, The Ages of American Law (Yale University Press, New Haven, 1977), 95.

89. See Brooktree Corp. v. Advanced Micro Devices, 977 F.2d 1555 (Fed. Cir. 1992).

90. See Mark A. Lemley et al., Software and Internet Law (Aspen, New York, 2000), 411 (making this point).

91. Cf. 35 U.S.C. \$103(b).

92. See In re Ochiai, 71 F.3d 1565 (Fed. Cir. 1995). 
93. See Mark D. Janis and Jay P. Kesan, "US Plant Variety Protection: Sound and Fury . . . ?" Houston Law Review 39 (2002):727; Stephen M. Maurer, P. Bernt Hugenholz, and Harlan J. Onsrud, "Europe's Database Experiment," Science 294 (2001); 789.

94. See Guido Calabresi, A Common Law for the Age of Statutes (Harvard University Press, Cambridge,1982).

95. See Suzanna Sherry, "Haste Makes Waste: Congress and the Common Law in Cyberspace," Vanderbilt Law Review 55 (2002): 309 (arguing that the common law rulemaking is better suited to rapid technological change).

96. See Daniel A. Farber and Philip P. Frickey, "The Jurisprudence of Public Choice," Texas Law Review 65 (1987): 873.

97. On the unnecessary complexity of the copyright laws, see Jessica Litman, Digital Copyright (Prometheus Books, Amherst, 2001), 25; Jessica Litman, "Revising Copyright Law for the Information Age," Oregon Law Review 75 (1996): 19, 22-23; Jessica Litman, "The Exclusive Right to Read," Cardozo Arts and Entertainment Law Journal 13 (1994): 29, 34 (1994).

98. In particular 35 U.S.C. §103(b) (biotechnological processes), §155A (private patent relief), $\$ 156$ (pharmaceutical patent term extension), and $\$ 287$ (medical process patents).

99. The Hatch-Waxman provisions, 35 U.S.C. \$156, in particular have been used on numerous occasions to violate the antitrust laws. Pharmaceutical patent owners have colluded with putative generic entrants to prevent that company or any other from entering the market. See Andrx Pharms, Inc. v. Biovail Corp., 256 F.3d 799 (D.C. Cir. 2001); In re Cardizem CD Antitrust Litigation, 105 F. Supp. 2d 682 (E.D. Mich. 2000).

100. Gilmore, "Ages of American Law," 96. Cited in note 88.

101. Ibid.

102. The antitrust laws are an obvious example of the latter. The few sentences of Sherman Act section 1 and 2, 15 U.S.C. \$\$1-2 (2000), have spawned a vast set of judicially created standards for identifying and punishing anticompetitive behavior. 103. See, e.g., Richard Gilbert and Carl Shapiro, "Optimal Patent Length and Breadth," RAND Journal of Economics 21 (1990): 106 (emphasizing the importance of patent scope to incentives); Robert P. Merges and Richard R. Nelson, "On the Complex Economics of Patent Scope," Columbia Law Review 90 (1990): 839 (same). 104. See Calabresi, "A Common Law," 46-47. Cited in note 94.

105. Ibid., 48.

106. See in Dickinson v. Zurko, 527 U.S. 150, 161-62 (1999).

107. Cf. Rochelle Cooper Dreyfuss, "The Federal Circuit: A Case Study in Specialized Courts," New York University Law Review 64 (1989): 1. 